\title{
Determination of the optimal production volume of the industrial enterprise
}

\author{
Elena Matys ${ }^{1,{ }^{*}}$, Natalia Meller ${ }^{1}$, Inna Nekrasova $^{1}$, and Elena Rechapova ${ }^{2}$ \\ ${ }^{1}$ Tyumen Industrial University, Volodarskogo str., 38, Tyumen, 625000, Russia \\ ${ }^{2}$ Tyumen State University, Volodarskogo str., 6, Tyumen, 625001, Russia
}

\begin{abstract}
The article observes the methodology and practices of formulating and solving the problem of resource distribution for the industrial enterprise effective management. Methods and models of linear programming are widely used when solving problems of economical and efficient use of resources. One of the tasks solved by the method of linear programming is to determine the optimal production volume having limited resources. The implementation of the found optimal plan will ensure the achievement of the company's goal of maximum efficiency. Secondly, the mobilization of surplus resources within the identified reserves will increase the efficiency of the industrial enterprise, and thus stabilize its market positions.
\end{abstract}

\section{Introduction}

The industrial enterprise resourcing is the main function, the implementation of which determines the degree of development of any economic entity and the effectiveness of its functioning. Studying the patterns of resourcing is necessary for the rational, efficient and contemporary formation and distribution of resources used to perform work across all cycles. Resources are the capabilities of an enterprise whose strategic importance lies, first, in the source of formation for developing an optimal strategy of the subject, secondly, in the way of using when dealing with the environment, and thirdly, in the specific course of the subject's action. The use of resources of an industrial enterprise is most rationally characterized by such concepts as productivity and efficiency. Productivity provides the activity of each resource with a specific indicator, and efficiency represents its significance from the point of view of systematic use. In practice, the main methods of diagnosing various components of the enterprise's potential are expertise, point, rating comparative analyses, factor analysis, economic and mathematical modeling, computer-aided simulation modelling [1-4].

\section{Method}

\footnotetext{
*Corresponding author: a.copytowa@yandex.ru
} 
When solving problems of economical and efficient use of resources, methods and models of linear programming are widely used. One of the tasks solved by the method of linear programming is to determine the optimal production volume having limited resources

The task: "Define the production plan of four types of products P1, P2, P3, P4. Three types of resources are used for their production: labor, material and financial resources. The quantity of each i-type of resource to produce each $\mathrm{j}$-kind of product is called the expenditure rate and is denoted by aij. The quantity of each type of resource available is denoted by bi, and the limiting output boundaries are cij "[2].

Table 1. Initial data.

\begin{tabular}{|c|c|c|c|c|c|}
\hline \multirow{3}{*}{$\begin{array}{l}\text { Resources } \\
\text { (i) }\end{array}$} & \multicolumn{4}{|c|}{ The type of product (j) } & \multirow{3}{*}{$\begin{array}{l}\text { Resource } \\
\text { reserve (bi) }\end{array}$} \\
\hline & P1 & $\mathrm{P} 2$ & P3 & $\mathrm{P} 4$ & \\
\hline & \multicolumn{4}{|c|}{ Specific resource consumption (aij) } & \\
\hline Labor & a11 & a12 & a13 & a14 & b1 \\
\hline Material & $\mathrm{a} 21$ & $\mathrm{a} 22$ & a23 & $\mathrm{a} 24$ & b2 \\
\hline Financial & a31 & a32 & a33 & a34 & b3 \\
\hline \multicolumn{6}{|l|}{ Border: } \\
\hline lower & $\mathrm{c} 11$ & $\mathrm{c} 12$ & $\mathrm{c} 13$ & $\mathrm{c} 14$ & \\
\hline upper & $\mathrm{c} 21$ & $\mathrm{c} 22$ & $\mathrm{c} 23$ & c24 & \\
\hline plan & $\mathrm{x} 1$ & $\mathrm{x} 2$ & $\mathrm{x} 3$ & $\mathrm{x} 4$ & \\
\hline
\end{tabular}

The initial data on the specific consumption of each type of resource are given in accordance with the regulatory, technical and technological, and financial documentation of the enterprise. So, the expenditure rate of material resources can be taken from routing sheets. The expenditure rate of labor intensity - from the standard-rate statements or cards of technological processes, financial expenditure rate -from the accounting reports. Moreover, the line "Labor resources" shows the consolidated labor intensity of the production in the standard number of hours as the total for all its operations. The line "Material resources" shows the expenditure rate of the scarcest (most limited) type of materials in the units of measurement (tons, $\mathrm{kg}, \mathrm{m}, \mathrm{l}$, etc.). In addition, it is possible to provide all the initial data of the table in monetary units according to the line "Financial Resources". The specific consumption of financial resources can be understood, for example, as the capital intensity of each product production due to the need for investment in a new construction or reconstruction of a functioning enterprise [5-9].

To state the distribution of resources in a short form, we denote resources by $F$, the result of their application by $\mathrm{R}$. So, according to the dependencies of the result and the resources expended on the number of products produced, $R=R(x j), F=F(x j)$ it can be taken for the first setting:

$$
\left\{\begin{array}{c}
L_{1}=R\left(x_{j}\right) \rightarrow \max _{;} \\
F\left(x_{i j} \leq F^{*}\right.
\end{array}\right.
$$

for the second setting:

$$
\left\{\begin{array}{c}
L_{2}=R\left(x_{j}\right) \rightarrow \min \\
F\left(x_{j}\right) \leq F^{*} \\
R\left(x_{j}\right) \leq R^{*}
\end{array}\right.
$$


$\mathrm{F} *, \mathrm{R}^{*}$ - given (planned or predicted) values of resources and result.

To form a model in this or that setting, additional information on the single productivity of production and sales of each product type will be needed, for example, the profit from the sale of a unit of each product type and the planned profit in general from the production of all products [9-12].

For products of the types P1, P2, P3, P4, it will be p1, p2, p3, p4, of monetary units, and the total profit of production in general must be at least $\mathrm{Z}$ monetary units. So, for the first statement, the objective function is added to the previously compiled system of constraints and boundary conditions and the following mathematical model is obtained:

$$
\left\{\begin{array}{c}
\max L 1=p 1 \times 1+p 2 \times 2+p 3 \times 3+p 4 x 4 \\
\mathrm{a} 11 \times 1+\mathrm{a} 12 \mathrm{x} 2+\mathrm{a} 13 \times 3+\mathrm{a} 14 \times 4 \leq b 1 \\
\mathrm{a} 21 \mathrm{x} 1+\mathrm{a} 22 \mathrm{x} 2+\mathrm{a} 23 \times 3+\mathrm{a} 24 \mathrm{x} 4 \leq \mathrm{b} 2 \\
\mathrm{a} 31 \times 1+\mathrm{a} 32 \mathrm{x} 2+\mathrm{a} 33 \times 3+\mathrm{a} 34 \mathrm{x} 4 \leq \mathrm{b} 3 \\
\mathrm{c} 11 \leq \mathrm{x} 1 \leq \mathrm{c} 21 ; \mathrm{c} 12 \leq \mathrm{x} 2 \leq \mathrm{c} 22 \\
\mathrm{c} 13 \leq \mathrm{x} 3 \leq \mathrm{c} 23 ; \mathrm{c} 14 \leq \mathrm{x} 4 \leq \mathrm{c} 24
\end{array}\right.
$$

For the second statement, provided that y1, y2, y3 - reserves for resources, and maximizing their amount ensures the minimization of resources used.

$$
\left\{\begin{array}{c}
\min L 2=y 1+y 2+y 3 ; \mathrm{a} 11 \times 1+\mathrm{a} 12 \mathrm{x} 2+\mathrm{a} 13 \mathrm{x} 3+\mathrm{a} 14 \mathrm{x} 4 \leq b 1 \\
\mathrm{a} 21 \mathrm{x} 1+\mathrm{a} 22 \mathrm{x} 2+\mathrm{a} 23 \times 3+\mathrm{a} 24 \mathrm{x} 4 \leq \mathrm{b} 2 \\
\mathrm{a} 31 \mathrm{x} 1+\mathrm{a} 32 \mathrm{x} 2+\mathrm{a} 33 \mathrm{x} 3+\mathrm{a} 34 \mathrm{x} 4 \leq \mathrm{b} 3 \\
\mathrm{c} 11 \leq \mathrm{x} 1 \leq \mathrm{c} 21 ; \mathrm{c} 12 \leq \mathrm{x} 2 \leq \mathrm{c} 22 \\
\mathrm{c} 13 \leq \mathrm{x} 3 \leq \mathrm{c} 23 ; \mathrm{c} 14 \leq \mathrm{x} 4 \leq \mathrm{c} 24 \\
y 1, y 2, y 3 \geq 0
\end{array}\right.
$$

\section{Results}

It is necessary to define a plan to produce four types of products P1 - Pump station for pumping the NPS, P2 - Block for combing BG, P3- Block for gas condensate studies of wells, P4 - Measuring device "Mera MM". To produce these products three types of resources are used: labor, material and financial. The initial data are presented in Table 2.

\begin{tabular}{|c|c|c|c|c|c|}
\hline \multirow{3}{*}{ Resources (i) } & \multicolumn{4}{|c|}{ The type of product ( $\mathrm{j}$ ) } & \multirow{3}{*}{$\begin{array}{l}\text { Resource } \\
\text { reserve (bi) }\end{array}$} \\
\hline & P1 & P2 & P3 & P4 & \\
\hline & \multicolumn{4}{|c|}{ Specific resource consumption (aij) } & \\
\hline Labor & 1972,9 & 263,53 & 200 & 1595,9 & 465496,64 \\
\hline Material & 3172108 & 319257 & 997148 & 2069148 & 749512400 \\
\hline Financial & 3332701,1 & 563393,5 & 428882 & 1094598,1 & 490883000 \\
\hline \multicolumn{6}{|c|}{ Border: } \\
\hline upper & 9 & 200 & 150 & 200 & - \\
\hline lower & 18 & & & & - \\
\hline plan & $\mathrm{x} 1$ & $\mathrm{x} 2$ & $\mathrm{x} 3$ & $\mathrm{x} 4$ & - \\
\hline
\end{tabular}

Table 2. Input data. 
Table 1 shows that for a release of one product, for example, the product of type P3, 200 units of labor resources are required, type P2 - 319257 units of material resources, etc. The enterprise has 490883000 rubles of financial resources, 749512400 rub. of material resources and 465,496.64 rubles. of labor resources. Based on market demand and production-technological capabilities (production capacity, the level of specialization, minimum production volume), the upper and lower limits for the output of each product type (in monetary units) have been established [12-18].

The expenditure rate of resources for each product manufactured by the enterprise is calculated and is presented in monetary units. According to the initial data mathematical model is developed to determine the production plan for the products.

Let $\mathrm{x} 1, \mathrm{x} 2, \mathrm{x} 3, \mathrm{x} 4$ be the number of products of types P1, P2, P3, P4 to be determined. Table 2 shows that to produce one $\mathrm{P} 1$ product, 1972.9 units of labor resources are required, P2, P3, P4 - 263.53, 200, 1595.9 units of labor resources. So, the required labor resource for the output of all types of products will be equal to $1972,91+263,53 \times 2+200 \times 3+$ $1595,9 x 4$.

Obviously, the required resource cannot exceed the available one, so for the labor

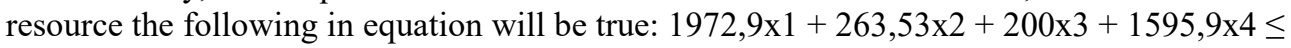
465496,64, where 465700 is the disposable resource.

If we create similar dependencies for other types of resources and add the maximum permissible values, we get the system:

$$
\left\{\begin{array}{c}
1972,9 \times 1+263,53 \times 2+200 \times 3+1595,9 \times 4 \leq 465496,64 \\
3172108 \times 1+319257 \times 2+997148 \times 3+2069148 \times 4 \leq 749512400 \\
3332701 \times 1+563393,5 \times 2+428882 \times 3+1094598 \times 4 \leq 490883000 \\
x 1, x 2, x 3, x 4 \geq 0
\end{array}\right.
$$

If additional variables $\mathrm{y} 1 \geq 0, \mathrm{y} 2 \geq 0, \mathrm{y} 3 \geq 0$ are introduced into the in equations, then we can state:

$$
\left\{\begin{array}{c}
1972,9 \mathrm{x} 1+263,53 \mathrm{x} 2+200 \mathrm{x} 3+1595,9 \mathrm{x} 4+\mathrm{y} 1=465496,64 \\
3172108 \mathrm{x} 1+319257 \mathrm{x} 2+997148 \mathrm{x} 3+2069148 \mathrm{x} 4+\mathrm{y} 2=749512400 \\
3332701 \mathrm{x} 1+563393,5 \mathrm{x} 2+428882 \times 3+1094598 \times 4+\mathrm{y} 3=490883000
\end{array}\right.
$$

The profit of products of types P1, P2, P3, P4 is planned in the amount of 1002370 , 136013, 219711 and 487621 rubles. and the total profit from the production should be at least 190,000,000 rubles.

For the first statement, we add the objective function to the system of constraints and boundary conditions that have already been created and obtain a mathematical model:

$$
\left\{\begin{array}{c}
\max L 1=1002370 x 1+136013 \times 2+219711 x 3+487621 \times 4 \\
1972,9 \times 1+263,53 \times 2+200 \times 3+1595,9 \times 4 \leq 465496,64 \\
3172108 \times 1+319257 \times 2+997148 \times 3+2069148 \times 4 \leq 749512400 \\
3332701 \times 1+563393,5 \times 2+428882 \times 3+1094598 \times 4 \leq 490883000 \\
x 1, x 2, x 3, x 4 \geq 0
\end{array}\right.
$$

For the second statement: 


$$
\left\{\begin{array}{c}
\min L 2=y 1+y 2+y 3 \\
1002370 x 1+136013 \times 2+219711 x 3+487621 x 4 \geq 1900000000 \\
1972,9 \times 1+263,53 \times 2+200 \times 3+1595,9 \times 4 \leq 465496,64 \\
3172108 \times 1+319257 \times 2+997148 \times 3+2069148 \times 4 \leq 749512400 \\
3332701 \times 1+563393,5 \times 2+428882 \times 3+1094598 \times 4 \leq 490883000 \\
x 1, x 2, x 3, x 4, y 1, y 2, y 3 \geq 0
\end{array}\right.
$$

According to the solution of the problem in two different formulations (Table 3), the results of the solution are also different.

Table 3. Results of solving the problem.

\begin{tabular}{|c|c|c|c|c|c|c|}
\hline $\begin{array}{l}\text { Formul } \\
\text { ation }\end{array}$ & $\begin{array}{c}\text { The } \\
\text { objective } \\
\text { function }\end{array}$ & $\begin{array}{l}\text { Limiting } \\
\text { conditions }\end{array}$ & R0 & F0 & $\mathrm{x} 10$ & $\mathrm{x} 20$ \\
\hline 1 & $\mathrm{R} 0 \rightarrow \max$ & $\begin{array}{c}F \leq 1240860896 \\
64\end{array}$ & 189909794 & 1232779660 & 18 & 218 \\
\hline 2 & $\mathrm{~F} 0 \rightarrow \min$ & $\mathrm{R} \geq 190000000$ & 190288456 & 1235237694 & 17 & 212 \\
\hline $\begin{array}{c}\text { Formul } \\
\text { ation }\end{array}$ & $\mathrm{x} 30$ & $\mathrm{x} 40$ & y10 & y20 & $\mathrm{y} 30$ & \\
\hline 1 & 179 & 211 & 0 & 7736710 & 344526,64 & \\
\hline 2 & 189 & 211 & 1554,08 & 2852780 & 2769268,56 & \\
\hline
\end{tabular}

\section{Discussion}

According to the calculations, it can be noted:

- In the first formulation of the problem, when maximizing profit, the value L1 = 189909794 roubles was obtained with the total amount of resources used $\mathrm{F}=1232779660$ rub. The resources turned out to be subdivided into two groups: limiting "Labor resources" for which yi $=0$, and unlimiting "Material resources" and "Financial resources" for which yi $>0$. The increase in the amount of labor resources will allow to find such a new optimal production and sale plan, which will lead to the increase in profits, so the increase in material and financial resources for which there are reserves in the volumes y2 $=7736710$ and $y 3=344526.64$ roubles will not lead to the increase in profits. Hence it follows that to increase the efficiency of production (the increase in the profit of the enterprise), it will not be necessary to increase the reserves of all resources, but only the limiting ones.

- in the second formulation, the total resource consumption turns out to be greater and amounts to $\mathrm{F}=1235237694$ roubles and for all kinds of products there are resources.

\section{Conclusion}

Thus, the results of an optimization analysis of the resource distribution problem in two statements make it possible to draw the following very significant conclusions for the effective management of an industrial enterprise:

1) the implementation of the optimal plan will ensure the achievement of maximum efficiency of an industrial enterprise (or to maximize the possible amount of profit from sales, or to minimize the consumption of the most important resources for the enterprise), especially if its products are competitive;

2) the implementation of the plan will be possible even if there is a release of funds due to surplus stocks of resources (beyond those required to fulfill these plans). The implementation of surplus resources within the identified reserves will further increase the efficiency of an industrial enterprise, and thus stabilize its market positions. 


\section{References}

1. D. Izvin, V. Lez'Er, A. Kopytova, MATEC Web of Conferences 170, 01065 (2018) DOI: $10.1051 /$ matecconf $/ 201817001065$

2. V. Lezier, M. Gusarova, A. Kopytova, IOP Conference Series: Earth and Environmental Science 90(1), 012069 (2017) DOI: 10.1088/1755-1315/90/1/012069

3. L.A. Ganieva, Formation and economic evaluation of resource potential of industrial enterprise («LAN» publishing, $\mathrm{SPb}, 2009$ )

4. V.V. Glukhov, M.D. Mednikov, S.B. Korobko, Mathematical methods and models of management («LAN» publishing, SPb, 2000)

5. N. Zotkina, M. Gusarova, A. Kopytova, Advances in Intelligent Systems and Computing 692, 1204-1213 (2018) DOI: 10.1007/978-3-319-70987-1_129

6. V. Lezier, M. Gusarova, A. Kopytova, IOP Conference Series: Earth and Environmental Science 90(1), 012034 (2017) DOI: 10.1088/1755-1315/90/1/012034

7. A. Kopytova, MATEC Web of Conferences 106, 08056 (2017) DOI: 10.1051/matecconf/201710608056

8. A.V. Kopytova, Exchange of intellectual property 3(XIV), 31-37 (2015)

9. A. Kopytova, Procedia Engineering 165, $1132 \quad$ (2016) DOI: 10.1016/j.proeng.2016.11.830

10. N. Semeryanova, O. Fedorenko, A. Kopytova, MATEC Web of Conferences 239, 04013 (2018) DOI: 10.1051/matecconf/201823904013

11. N. Zotkina, A. Kopytova, M. Zenkina, O. Zhigunova, MATEC Web of Conferences 106, 08058 (2017) DOI: 10.1051/matecconf/201710608058

12. A.V. Kopytova, N.S. Zotkina, I.G. Reshetnikova, MATEC Web of Conferences 239, 04012 (2018) DOI: 10.1051/matecconf/201823904012

13. N. Zotkina, S. Bardasov, M. Gusarova, A. Kopytova, MATEC Web of Conferences 106, 08050 (2017) DOI: 10.1051/matecconf/201710608050

14. V. Lez'Er, M. Gusarova, A. Kopytova, MATEC Web of Conferences 170, 01066 (2018) DOI: $10.1051 /$ matecconf/201817001066

15. O. Frolova, A. Kopytova, E. Matys, MATEC Web of Conferences 170, 01064 (2018) DOI: $10.1051 /$ matecconf/201817001064

16. Y.V. Truntsevsky, I.I. Lukiny, A.V. Sumachev, A.V. Kopytova, MATEC Web of Conferences 170, 01067 (2018) DOI: 10.1051/matecconf/201817001067

17. L.F. Kazanskaya and O.M. Smirnova. International Journal of Civil Engineering and Technology, 9(11), 3006-3012 (2018)

18. Yu.A. Belentsov and O.M. Smirnova, International Journal of Civil Engineering and Technology, 9(11), 2999-3005 (2018) 